\title{
Monitoring brain functioning with evident based IT-technologies with feedback control
}

\author{
Ulyana B Lushchyk ${ }^{1 *}$, Viktor V Novytskyy ${ }^{1}$, Igor P Babii ${ }^{2}$, Nadiya G Lushchyk ${ }^{2}$, Olena V Babyuk ${ }^{2}$, Andriy O Kovpak ${ }^{3}$, \\ Ivanna I Legka ${ }^{3}$
}

From EPMA-World Congress 2013

Brussels, Belgium. 20-21 September 2013

\section{Scientific objectives}

Researches on brain functions, forming of algorithms of neuronets' functioning and attempt of their active correction are priority in medicine. With IT medical technologies the brain function research like EEG and transcranial electro-stimulation gains new significance and should be revised. Application of methodology for clinical interpretation in the estimation of the brain bioelectric activity allows creating a universal technology for estimation and individually oriented monitoring and correction of brain functions with the purpose of improvement of neurone conductivity, reactivity of cerebral tissues to stimuli, balancing of excitation and inhibition processes [1].

\section{Results interpretation}

During 17 years the Veritas Research Center has investigated sanogenic and pathological reconstructions in the brain bioelectric activity in patients of different type - from healthy to non-curable. $33 \%$ of all vascular patients were less curable (hemodynamically marked stenosises of the major arteries, combined cardiovascular insufficiency of II and III stages) and $48 \%$ of all psychoneurological patients (apallic syndrome, multiple sclerosis, lateral amyotrophic sclerosis, autism, ICP, epilepsy). The dynamics of brain bioelectric activity testified to large potential in functional activity of the brain, necessity in formation of new algorithms and IT-technologies for monitoring neurodynamics in the treatment process $[2,3]$.

\section{Outlook and expert recommendations}

Applying the IT-technology allows optimizing work of a medical staff, increase efficiency of costs on treatment due to the individually oriented approach to prediction

\footnotetext{
* Correspondence: u.lushchyk@gmail.com

${ }^{1}$ Research Center Veritas, 31 Obolonska Str., of. 9, Kyiv, 04071, Ukraine

Full list of author information is available at the end of the article
}

of treatment results and active medical management on the basis of evidential medicine and monitoring of sanogenic reconstructions [2].

\section{Authors' details}

${ }^{1}$ Research Center Veritas, 31 Obolonska Str., of. 9, Kyiv, 04071, Ukraine. ${ }^{2}$ The Clinic of Healthy Vessels, 4 Williams Str., Kyiv, 03191, Ukraine. ${ }^{3}$ Center for Innovative Medical Technologies Veritas IT Med, 4 Williams Str., Kyiv, 03191, Ukraine.

Published: 11 February 2014

\section{References}

1. Lushchyk UB, Novytskyy W: Polyvector dynamic diagnostics of the vascular systems. A modern innovative medical technology: from local examinations to integrative comprehension of the whole system. Med Devices 2008, 3:64-67.

2. Lushchyk UB, Babii IP, Titenko TM, Novytskyy W, Stukalin VO, Lushchyk NG, Leonova W, Priz AM: Innovative vectors in neurorehabilitation. Logic and management of multidisciplinary approach in restorative medicine. In Macros. Volume 244. Kyiv; 2012.

3. Lushchyk UB, Novytskyy W, Alexeyeva TS, Francevich KA, Branytska NS: Analytical aspects of an individual hemodynamic correction in the angioneurology. In Istyna. Volume 130. Kyiv; 2006.

doi:10.1186/1878-5085-5-S1-A100

Cite this article as: Lushchyk et al: Monitoring brain functioning with evident based IT-technologies with feedback control. EPMA Journal 2014 5(Suppl 1):A100.

Submit your next manuscript to BioMed Central and take full advantage of:

- Convenient online submission

- Thorough peer review

- No space constraints or color figure charges

- Immediate publication on acceptance

- Inclusion in PubMed, CAS, Scopus and Google Scholar

- Research which is freely available for redistribution 